\title{
The utility of liver function tests and abdominal ultrasound in infectious mononucleosis - A systematic review
}

\author{
E Tian $\operatorname{Tan}^{1}$, Danielle Wilkinson ${ }^{2}$, and Ovie Edafe ${ }^{3}$ \\ ${ }^{1}$ Barnsley District General Hospital \\ ${ }^{2}$ Rotherham General Hospitals NHS Trust \\ ${ }^{3}$ Sheffield Teaching Hospitals NHS Foundation Trust
}

February 7, 2022

\begin{abstract}
Introduction: A large proportion of patients with infectious mononucleosis (IM) have abnormal liver function tests (LFT) at presentation. There is no guideline regarding the management and follow-up of these patients. Some patients also have abdominal ultrasound due to deranged LFT, the need for this practice is unclear. The aim of this systematic review was to evaluate the evidence base on LFT assessment in IM, time to resolution of derangement, and the role of abdominal ultrasound. Methods: A systematic search of PubMed, EMBASE and the Cochrane library was done. Two authors independently screened records for eligibility using pre-defined criteria. We included both adult and paediatric populations. Quality assessment of included studies was done. Results: A total of 3924 patients were included from 32 studies. A combination of typical clinical features, heterophile antibodies and EBV-specific antibodies were used to ascertain diagnosis. The following proportion of patients had abnormal LFTs: AST (57\%); ALT (62\%); ALP (65\%); Bilirubin (16\%); GGT (41\%). Reported median (i.q.r.) time to resolution of LFT was $8(6-12)$ weeks. Maximum time to resolution was $>6$ months. Clinical hepatomegaly and splenomegaly were found in $35 \%$ and $44 \%$ of patients respectively. Enlarged liver and spleen on ultrasound were seen in 16/29 (55\%) and $38 / 38$ (100\%) of patients respectively. There were no reports of decompensated liver disease. Conclusion: Derangement in LFTs can persist over six months from initial presentation in IM. However, this is self-limiting. The evidence suggests serial liver function assessments and ultrasound abdomen are not required in immunocompetent patients with subclinical derangement in LFTs.
\end{abstract}

\section{Abstract \\ Introduction}

A large proportion of patients with infectious mononucleosis (IM) have abnormal liver function tests (LFT) at presentation. There is no guideline regarding the management and follow-up of these patients. Some patients also have abdominal ultrasound due to deranged LFT, the need for this practice is unclear. The aim of this systematic review was to evaluate the evidence base on LFT assessment in IM, time to resolution of derangement, and the role of abdominal ultrasound.

\section{Methods}

A systematic search of PubMed, EMBASE and the Cochrane library was done. Two authors independently screened records for eligibility using pre-defined criteria. We included both adult and paediatric populations. Quality assessment of included studies was done.

\section{Results}

A total of 3924 patients were included from 32 studies. A combination of typical clinical features, heterophile antibodies and EBV-specific antibodies were used to ascertain diagnosis. The following proportion of patients 
had abnormal LFTs: AST (57\%); ALT (62\%); ALP (65\%); Bilirubin (16\%); GGT (41\%). Reported median (i.q.r.) time to resolution of LFT was 8 (6-12) weeks. Maximum time to resolution was $>6$ months. Clinical hepatomegaly and splenomegaly were found in $35 \%$ and $44 \%$ of patients respectively. Enlarged liver and spleen on ultrasound were seen in 16/29 (55\%) and 38/38 (100\%) of patients respectively. There were no reports of decompensated liver disease.

\section{Conclusion}

Derangement in LFTs can persist over six months from initial presentation in IM. However, this is selflimiting. The evidence suggests serial liver function assessments and ultrasound abdomen are not required in immunocompetent patients with subclinical derangement in LFTs.

\section{Word count: 250 words}

Keywords: Infectious mononucleosis; glandular fever; liver function; abdomen ultrasound; Epstein-Barr virus

\section{5 succinct key points}

- Derangement in liver enzymes is common in patients with infectious mononucleosis.

- The reported median time to resolution of deranged liver function tests is 8 weeks but can persist beyond six months in a minority of patients.

- Deranged LFTs caused by infectious mononucleosis is self-limiting in majority of patients.

- Evidence suggests serial blood tests until resolution is not required in immunocompetent patients with subclinical derangement in LFTs.

- Routine abdominal ultrasound is not required in IM to investigate deranged liver function test in immunocompetent patients with subclinical derangement in LFTs.

\section{Introduction}

Infectious mononucleosis (IM) is a relatively common presentation to the Ear, Nose and Throat (ENT) department, with patients being admitted for symptomatic relief and hydration. These are generally young patients without medical comorbidities. The Epstein-Barr virus (EBV) is the most common cause of IM, with the remainder due to other viruses including cytomegalovirus (CMV), toxoplasmosis, and HIV. ${ }^{1}$

In patients with clinically suspected IM and atypical lymphocytosis, the diagnosis is generally confirmed with the monospot test. However, there is a false negative rate in up to $25 \%$ of adults in the first week of symptoms. $^{2}$

There is abnormality in liver function tests (LFT) in a large proportion of patients presenting with IM but this is usually self-limiting. ${ }^{2}$ Patient admitted to hospital generally would have standard LFTs as part of initial work up for IM. The utility of this is unclear, however, it may support diagnosis in the first week of illness if the monospot test was falsely negative. In addition, in settings where there is no available screening or definitive tests for IM, deranged LFTs may support clinical diagnosis taken in conjunction with clinical symptoms.

Practice varies with regards to follow-up in patients with IM and abnormal LFTs. Although a self-limiting finding, an initially abnormal LFTs generally start a cascade for further tests until normal. Anecdotally, general practitioners are often asked to repeat LFTs at varying intervals following discharge from hospital to ensure resolution. There are no guidelines to inform this practice. In addition, some centres routinely do abdominal ultrasound to evaluate the liver and spleen in patients with IM and abnormal LFTs; the need for this practice is unclear.

This systematic review aims to evaluate evidence base on LFTs assessment and ultrasound abdomen in IM. Specifically, we sought to determine the proportion of patients with abnormal LFTs, time to resolution of abnormal LFTs from clinical presentation, findings on abdominal ultrasound, and occurrence of decompensated liver disease. 


\section{Methods}

A systematic search of PubMed, EMBASE and Cochrane library was done with no restriction on publication date. The following search strategy was used: [infectious mononucleosis OR glandular fever] AND [liver function* OR liver enzyme* OR ultrasound]. Two authors (ETT, DW) independently screened title and abstract according to prespecified criteria and full texts of relevant articles were retrieved for further eligibility assessment. References of included full text articles were further screened for relevant studies. Any discrepancies on study eligibility were discussed with a third author (OE) and resolved accordingly.

We included all original studies evaluating any form of LFTs and/or abdominal ultrasound (USS) in both adult and/or paediatric patients with suspected or confirmed diagnosis of IM. Standard LFTs included any of the following: Aspartate Transaminase (AST), Alanine Transaminase (ALT), Alkaline Phosphatase (ALP), Bilirubin, Albumin, Total protein and Gamma-Glutamyltransferase (GGT). Abdominal ultrasound included liver and/or spleen and/or gallbladder ultrasound. We excluded studies evaluating patients with solely viral hepatitis (i.e. not related to clinical presentation of infectious mononucleosis), reviews, non-human studies, conference abstracts, letters/commentaries, expert opinions or recommendations, case reports and studies not published in English.

A standardized data collection proforma was used. This was initially piloted on five studies by all authors and revised accordingly. Subsequent data collection was by one author (DW) and checked for accuracy by a second author (ETT). In case of duplicate publications, we included the manuscript with the most complete data. The following data items were extracted: study characteristics, participants' demographics, method of ascertainment of IM, evaluation of LFTs, clinical findings on abdominal ultrasound and complications relating to liver disease. Our main outcomes are the proportion of patients with abnormal LFTs at presentation and time to resolution of LFTs. Secondary outcomes include presence of clinical hepatosplenomegaly, findings of abdominal ultrasound and any evidence of decompensated liver disease.

Quality assessment of included studies were performed using Murad's tool. ${ }^{3}$ Although the tool was originally developed for case series and case reports, this was discussed among the authors and deemed suitable for our review irrespective of study type as we were only extracting data relating to a single arm of interest. Data was expressed as count and percentages. Proportion of abnormal LFTs in individual studies were aggregated and an average calculated for all studies.

PRISMA reporting guideline was used in preparation of the manuscript.

\section{Results}

Figure 1 shows the PRISMA flow diagram for selection of studies. A total of 32 studies were included; one multicentered randomized controlled trial, seven case-control studies and the remaining were observational studies. Results of the quality assessment of included articles are shown in Table 1 . The studies included a total number of 3,924 patients. Five studies evaluated only adult population ${ }^{4-8}$; ten studies were on paediatric population (defined as under 18 years) ${ }^{9-18}$; ten studies included both adult and children $^{19-28}$; eight studies did not report on the participants' age ${ }^{29-36}$.

\section{Diagnosis of infectious mononucleosis}

Table 2 shows the different methods used to ascertain IM. Sixteen studies evaluated IM specifically caused by EBV using EBV-specific antibodies such as IgM and/or IgG with absence of EBNA while one study only evaluated CMV mononucleosis confirmed by CMV IgM ${ }^{6}$ and PCR. Thirteen studies used a combination of typical clinical symptoms (fatigue, fever, sore throat and swollen lymph nodes), presence of heterophile antibodies, and lymphocytosis or atypical lymphocytes to diagnose IM. Two studies did not report on method of diagnosis of IM ${ }^{30,19}$.

\section{Main outcomes}

We evaluated the proportion of patients with IM who had elevated LFTs in individual studies (Table 3). At presentation the following proportion of patients had elevated parameters: AST, 835/1472 (56.7\%); 
ALT, 957/1546 (61.9\%); ALP, 271/417 (65.0\%); Bilirubin, 188/1160 (16.2\%); GGT, 258/626 (41.2\%). Six studies did not differentiate between the transaminases and reported 435/891 (48.8\%) patients with raised values. Zhang et al. found reduce levels of total bilirubin in patients with IM compared to healthy control. Two studies included albumin within their testing and reported reduced albumin levels in 21/114 (18.4\%) patients $^{27,35}$.

Data on resolution of abnormal LFTs was largely incompletely reported (Table 3). Eleven studies reported following up patients with abnormal LFTs. Of these, eight studies reported maximum time to resolution of LFTs. The reported median (i.q.r.) time to complete resolution of all liver function parameters was 8 $(6-12)$ weeks. One study found persistently raised LFTs in a small number of patients after 6 months of presentation ${ }^{26}$.

\section{Secondary outcomes}

Eighteen studies reported on clinical findings of hepatomegaly;1039/2967 (35.0\%) patients were considered to have enlarged livers on clinical palpation. Twenty-one studies reported on clinical findings of splenomegaly,1311/3009 (43.6\%) patients were found to have enlarged palpable spleens on clinical examination.

Three studies reported on abdominal ultrasound findings in patients with IM ${ }^{4,11,24}$. In a case-control study, Ishibashi et al. found that all nine IM patients had significantly enlarged spleen on ultrasound. However, only three (33.3\%) had splenomegaly on clinical examination. Another study found that all 29 patients with IM had enlarged spleen on ultrasound and $16(55.2 \%)$ had enlarged liver ${ }^{24}$. Clinical findings of splenomegaly and hepatomegaly were $17.2 \%$ and $10.3 \%$ respectively in that study.

Mazur et al performed USS gallbladder on all IM patients and found 15/181 (8.3\%) of children had acute acalculous cholecystitis (AAC). The cohort with AAC reported right upper quadrant pain in addition to the typical clinical symptoms of IM. None required surgical intervention.

No additional interventions were reported in patients who had elevated bilirubin or clinical jaundice. There were no reports of decompensated acute or chronic liver disease among studies that followed patients for complications relating to IM.

\section{Discussion}

To our knowledge, this is the first systematic review to evaluate LFTs and USS in IM. Abnormal LFTs are an expected feature in IM; many units will routinely do blood tests to assess liver function on admission. The NICE clinical knowledge summary mentioned clinicians should consider blood test for LFTs in IM; based on expert opinion. ${ }^{37}$ The utility of this practice is unclear.

Our systematic review found around two thirds of patients had elevated transaminases; this is lower than other reports of $80-90 \%^{2}$. This difference may be attributed to timing of LFT measurements and the heterogenous population of the systematic review. It is commonly accepted that time to resolution of abnormal LFTs from presentation with IM is around three to four weeks ${ }^{38}$. However, the median reported time to resolution was eight weeks; a small minority of patients had persistent derangement after 6 months.

The population affected with IM are generally young and healthy. Evidence from the literature suggest serial measures of LFTs following discharge is not necessary, given the derangement in liver function is self-limiting, and no patient developed any sequalae of decompensated liver disease or received any intervention.

EBV infection is an extremely rare cause of acute liver failure. One US study included a total of 1887 adults with acute liver failure, they found four cases $(0.21 \%)$ were EBV-related acute liver failure. ${ }^{39}$ Three of these cases were considered to be "probable" EBV-related as EBV was not confirmed by serological tests and liver tissue biopsy. One out of the four of the patients was immunocompromised. Two patients did not have typical symptoms of IM. In addition, acute liver failure occurred in early disease; all presented with jaundice and median time from symptom to presentation with liver disease was 13 days. 
We also explored the role of abdominal ultrasound in IM. From the authors' experiences, some units will perform ultrasound to evaluate for hepatosplenomegaly in the context of deranged LFTs, however, this was not reflected in the literature as only two studies evaluated ultrasound of the abdomen. All patients were found to have splenomegaly and around half were found to have hepatomegaly. It is expected that patients would have hepatosplenomegaly as a consequence of IM, thus the advice to avoid contact sport is given to all patients. Although limited data on ultrasound, ultrasound findings did not influence management. It is worth noting that the presence of right upper quadrant pain in the context of IM may be suggestive of acalculous cholecystitis, ultrasound may be indicated here for further evaluation. ${ }^{11}$

Our findings also raise questions on the need for routine LFTs assessment in IM as this has the potential to lead to a cascade of unnecessary serial measurements in the community and abdominal ultrasound which has no effects on patients' outcomes.

Changing the practice with regards to serial LFTs assessment would avoid unnecessary use of limited resources, currently highlighted by national shortage of blood bottles in the UK. ${ }^{40}$ In addition, avoid unnecessary consultations with the general practitioners.

Limitations to this systematic review include the varied methods for ascertaining diagnosis of IM and incomplete follow up in LFT assessment with varying lengths of follow-up across studies. Even within studies, there is varying interval or lack of information for repeating LFTs among individual patients. Generally, there was no standardized protocol for assessment of LFTs, thus limiting accurate assessment of time to resolution. There are also few studies on abdominal ultrasound in IM patients.

\section{Conclusion}

In IM, serial LFTs assessment is not required in immunocompetent patients with subclinical derangement in liver function. In addition, routine abdominal ultrasound is not required to evaluate for abnormal LFTs. Derangement in LFTs can persist over six months from initial presentation but is self-limiting with no evidence of long term sequalae of liver failure.

\section{References}

1. Fugl A, Andersen CL. Epstein-Barr virus and its association with disease - a review of relevance to general practice. BMC Fam Pract . May 14 2019;20(1):62. doi:10.1186/s12875-019-0954-3

2. Lennon P, Crotty M, Fenton JE. Infectious mononucleosis. Bmj . Apr 21 2015;350:h1825. doi:10.1136/bmj.h1825

3. Murad MH, Sultan S, Haffar S, Bazerbachi F. Methodological quality and synthesis of case series and case reports. BMJ Evid Based Med . Apr 2018;23(2):60-63. doi:10.1136/bmjebm-2017-110853

4. Ishibashi H, Okumura Y, Higuchi N. Differentiation of mononucleosis from hepatitis by sonographic measurement of spleen size. Journal of Clinical Ultrasound . 1987;15(5):313-316. doi:http://dx.doi.org/10.1002/jcu.1870150504

5. ROSALKI SB, JONES TG, VERNEY AF. Transaminase and liver-function studies in infectious mononucleosis. Br Med J . Mar 26 1960;1(5177):929-32. doi:10.1136/bmj.1.5177.929

6. Sridhar S, Chung TWH, Chan JFW, et al. Emergence of cytomegalovirus mononucleosis syndrome among young adults in Hong Kong linked to falling seroprevalence: Results of a 14-year seroepidemiological study. Open Forum Infectious Diseases . 2018;5(10)doi:http://dx.doi.org/10.1093/ofid/ofy262

7. Kilpatrick ZM. Structural and functional abnormalities of liver in infectious mononucleosis. Arch Intern Med . Jan 1966;117(1):47-53.

8. Grotto I, Mimouni D, Huerta M, et al. Clinical and laboratory presentation of EBV positive infectious mononucleosis in young adults. Epidemiol Infect. Aug 2003;131(1):683-9. doi:10.1017/s0950268803008550 
9. Chan CW, Chiang AKS, Chan KH, Lau ASY. Epstein-Barr virus-associated infectious mononucleosis in Chinese children. Pediatric Infectious Disease Journal . 2003;22(11):974-978. doi:http://dx.doi.org/10.1097/01.inf.0000095199.56025.96

10. Gonzalez Saldana N, Monroy Colin VA, Pina Ruiz G, Juarez Olguin H. Clinical and laboratory characteristics of infectious mononucleosis by Epstein-Barr virus in Mexican children. BMC research notes . 2012;5:361. doi:http://dx.doi.org/10.1186/1756-0500-5-361

11. Mazur-Melewska K, Derwich A, Mania A, Kemnitz P, Sluzewski W, Figlerowicz M. Epstein-Barr virus infection with acute acalculous cholecystitis in previously healthy children. International Journal of Clinical Practice . 2019;73(9):1-6. doi:http://dx.doi.org/10.1111/ijcp.13386

12. Sohn MJ, Moon JS, Ko JS, Yang HR. EBV VCA IGM and cytomegalovirus igm dual positivity is a false positive finding related to age and hepatic involvement of primary epstein-barr virus infection in children. Journal of Pediatric Gastroenterology and Nutrition . 2017;65(Supplement 2):S313. North American Society for Pediatric Gastroenterology, Hepatology and Nutrition Annual Meeting 2017. United States. doi:http://dx.doi.org/10.1097/MPG.0000000000001805

13. Son KH, Shin MY. Clinical features of Epstein-Barr virus-associated infectious mononucleosis in hospitalized Korean children. Korean Journal of Pediatrics . 2011;54(10):409-413. doi:http://dx.doi.org/10.3345/kjp.2011.54.10.409

14. RL B, ES S. Infectious Mononucleosis in Childhood. USA: Clinical Paediatrics; 1967. p. 393-399.

15. Kanegane H, Kanegane C, Yachie A, Miyawaki T, Tosato G. Infectious mononucleosis as a disease of early childhood in Japan caused by primary Epstein-Barr virus infection. Acta Paediatr Jpn . Apr 1997;39(2):166-71. doi:10.1111/j.1442-200x.1997.tb03575.x

16. Gao LW, Xie ZD, Liu YY, Wang Y, Shen KL. Epidemiologic and clinical characteristics of infectious mononucleosis associated with Epstein-Barr virus infection in children in Beijing, China. World J Pediatr . Feb 2011;7(1):45-9. doi:10.1007/s12519-011-0244-1

17. Ginsburg CM, Henle W, Henle G, Horwitz CA. Infectious mononucleosis in children. Evaluation of Epstein-Barr virus-specific serological data.JAMA . Feb 21 1977;237(8):781-5. doi:10.1001/jama.237.8.781

18. Topp SK, Rosenfeldt V, Vestergaard H, Christiansen CB, Von Linstow ML. Clinical characteristics and laboratory findings in Danish children hospitalized with primary Epstein-Barr virus infection. Infect Dis (Lond) . 2015;47(12):908-14. doi:10.3109/23744235.2015.1082036

19. Herbinger KH, Hanus I, Felbinger TW, et al. Elevated values of clinically relevant transferases induced by imported infectious diseases: A controlled cross-sectional study of 14,559 diseased German travelers returning from the tropics and subtropics. American Journal of Tropical Medicine and Hygiene . 2016;95(2):481-487. doi:http://dx.doi.org/10.4269/ajtmh.16-0224

20. Horwitz CA, Henle W, Henle G, et al. Heterophil-negative infectious mononucleosis and mononucleosislike illnesses. Laboratory confirmation of 43 cases. American Journal of Medicine . 1977;63(6):947-957.

21. Massei F, Palla G, Ughi C, Talini I, Macchia P, Maggiore G. Cholestasis as a presenting feature of acute Epstein-Barr infection. Medico e Bambino . 2002;21(5):308-310. Colestasi nella mononucleosi infettiva da virus di Epstein-Barr.

22. Monteiro TAF, Costa IB, Correa TLDS, et al. Genotypes of Epstein-Barr virus (EBV1/EBV2) in individuals with infectious mononucleosis in the metropolitan area of Belem, Brazil, between 2005 and 2016. The Brazilian journal of infectious diseases : an official publication of the Brazilian Society of Infectious Diseases . 2020;doi:http://dx.doi.org/10.1016/j.bjid.2020.06.004

23. Gadeberg O, Andersen V, Cohn J. Clinical symptoms, immunoglobulin levels, immunoglobulin secreting 
cell numbers and mononuclear cell purine enzyme activities during the course of infectious mononucleosis.Danish Medical Bulletin . 1984;31(6):507-511.

24. Dommerby H, Stangerup SE, Stangerup M, Hancke S. Hepatosplenomegaly in infectious mononucleosis, assessed by ultrasonic scanning. J Laryngol Otol . May 1986;100(5):573-9. doi:10.1017/s0022215100099680

25. Henke CE, Kurland LT, Elveback LR. Infectious mononucleosis in Rochester, Minnesota, 1950 through 1969. Am J Epidemiol. Dec 1973;98(6):483-90. doi:10.1093/oxfordjournals.aje.a121577

26. Rea TD, Russo JE, Katon W, Ashley RL, Buchwald DS. Prospective study of the natural history of infectious mononucleosis caused by Epstein-Barr virus. J Am Board Fam Pract . 2001 Jul-Aug 2001;14(4):234-42.

27. GELB D, WEST M, ZIMMERMAN HJ. Serum enzymes in disease. IX. Analysis of factors responsible for elevated values in infectious mononucleosis. Am J Med. Aug 1962;33:249-61. doi:10.1016/00029343(62)90023-2

28. Wang Y, Li J, Ren YY, Zhao H. The levels of liver enzymes and atypical lymphocytes are higher in youth patients with infectious mononucleosis than in preschool children. Clin Mol Hepatol . Dec 2013;19(4):382-8. doi:10.3350/cmh.2013.19.4.382

29. Mygind N. Serial serum enzyme studies in infectious mononucleosis.Scandinavian Journal of Infectious Diseases . 1976;8(3):139-142.

30. Rotenberg Z, Harell D, Weinberger I, et al. Total lactate dehydrogenase and its isoenzymes in serum of patients with infectious mononucleosis. Clinical Chemistry . 1991;37(1):116-117.

31. Van der Horst C, Joncas J, Ahronheim G, et al. Lack of effect of peroral acyclovir for the treatment of acute infectious mononucleosis.Journal of Infectious Diseases . 1991;164(4):788-792. doi:http://dx.doi.org/10.1093/infdis/164.4.788

32. Zhang L, Zhou P, Meng Z, et al. Infectious mononucleosis and hepatic function. Experimental and Therapeutic Medicine . 2018;15(3):2901-2909. doi:http://dx.doi.org/10.3892/etm.2018.5736

33. Shuster F, Ognibene AJ. Dissociation of serum bilirubin and alkaline phosphatase in infectious mononucleosis. JAMA . Jul 14 1969;209(2):267-8.

34. FINKEL M, PARKER GW, FANSELAU HA. THE HEPATITIS OF INFECTIOUS MONONUCLEOSIS: EXPERIENCE WITH 235 CASES. Mil Med . Jun 1964;129:533-8.

35. BARON DN, BELL JL, DUNNET WN. BIOCHEMICAL STUDIES ON HEPATIC INVOLVEMENT IN INFECTIOUS MONONUCLEOSIS. J Clin Pathol . Mar 1965;18:209-11. doi:10.1136/jcp.18.2.209

36. Evans AS. LIVER INVOLVEMENT IN INFECTIOUS MONONUCLEOSIS. J Clin Invest . Jan 1948;27(1):106-10. doi:10.1172/JCI101913

37. National

Institute for Health and Care Excellence (NICE). Glandular fever (infectious

mononucleosis). Clinical Knowledge Summaries (CKS). 7 January 2022, https://cks.nice.org.uk/topics/glandular-fever-infectious-mononucleosis/

38. Kofteridis DP, Koulentaki M, Valachis A, et al. Epstein Barr virus hepatitis. Eur J Intern Med . Feb 2011;22(1):73-6. doi:10.1016/j.ejim.2010.07.016

39. Mellinger JL, Rossaro L, Naugler WE, et al. Epstein-Barr virus (EBV) related acute liver failure: a case series from the US Acute Liver Failure Study Group. Dig Dis Sci . Jul 2014;59(7):1630-7. doi:10.1007/s10620-014-3029-2

40. Rimmer A. What has caused the NHS blood tube shortage, and how is it affecting doctors and patients? Bmj . Sep 3 2021;374:n2174. doi:10.1136/bmj.n2174 
Figure 1 Prisma flow diagram showing study selection process

\begin{tabular}{|c|c|}
\hline Study & Selection \\
\hline Chan (2003) & {$[?]$} \\
\hline Gonzalez Sandana (2012) & {$[?]$} \\
\hline Herbinger (2016) & {$[?]$} \\
\hline Ishibashi (1987) & $\mathrm{X}$ \\
\hline Massei (2001) & {$[?]$} \\
\hline Mazur (2019) & {$[?]$} \\
\hline Monteiro (2020) & $\mathbf{X}$ \\
\hline Mygind (1976) & $\mathrm{X}$ \\
\hline Rotenburg (1991) & $\mathbf{X}$ \\
\hline Sohn $(2017)$ & {$[?]$} \\
\hline Son $(2011)$ & {$[?]$} \\
\hline Sridhar (2018) & {$[?]$} \\
\hline \#Vanderhorst (1991) & $\mathbf{X}$ \\
\hline Zhang (2017) & {$[?]$} \\
\hline Gadeberg (1984) & {$[?]$} \\
\hline Dommerby (1986) & {$[?]$} \\
\hline Baehner (1967) & {$[?]$} \\
\hline Kanegane (1997) & {$[?]$} \\
\hline Henke (1973) & {$[?]$} \\
\hline Rosalki (1960) & {$[?]$} \\
\hline Shuster (1967) & {$[?]$} \\
\hline Kilpatrick (1966) & {$[?]$} \\
\hline Grotto (2003) & {$[?]$} \\
\hline Gao (2011) & {$[?]$} \\
\hline Rea (2001) & {$[?]$} \\
\hline Ginsburg (1977) & {$[?]$} \\
\hline Gelb (1962) & $\mathbf{X}$ \\
\hline Finkel (1964) & {$[?]$} \\
\hline Wang (2013) & {$[?]$} \\
\hline Topp (2015) & {$[?]$} \\
\hline Baron (1965) & {$[?]$} \\
\hline Evans (1948) & {$[?]$} \\
\hline Case-control study \# Multicentre randomized controlled trial & $*$ Case-control study \# Multicentre randomized controlled \\
\hline
\end{tabular}

Table 1: Methodological assessment of included studies

Study

Chan (2003)

Gonzalez Sandana (2012)

Ishibashi (1987)

Massei (2001)

Mazur (2019)

Monteiro (2020)

Mygind (1976)

Sohn (2017)

Son (2011)

Sridhar (2018) 
Study

Vanderhorst (1991)

Zhang (2017)

Gadeberg (1984)

Dommerby (1986)

Baehner (1967)

Kanegane (1997)

Henke (1973)

Rosalki (1960)

Shuster (1967)

Kilpatrick (1966)

Grotto (2003)

Gao (2011)

Rea (2001)

Ginsburg (1977)

Gelb (1962)

Finkel (1964)

Wang (2013)

\#Topp (2015)

Baron (1965)

Evans (1948)

Evaluated CMV mononucleosis using CMV IgM and CMV PCR \# Used EBV PCR in addition to heterophile antibodies ar

Table 2 Method of diagnosis of infectious mononucleosis

\begin{tabular}{|c|c|c|}
\hline Study & Proportion of raised LFTs & $\begin{array}{l}\text { Maximum time to resolution of } \\
\text { LFTs }\end{array}$ \\
\hline $\begin{array}{l}\text { Chan (2003) Hong Kong } \mathrm{N}=77 \text {; } \\
\text { Paediatric }\end{array}$ & $\begin{array}{l}\text { ALT + AST - 59.2\% Bilirubin - } \\
5.6 \%\end{array}$ & 5.7 weeks \\
\hline $\begin{array}{l}\text { Gonzalez Sandana (2012) Mexico } \\
\mathrm{N}=163 \text {; Paediatric }\end{array}$ & $\begin{array}{l}\text { Transaminases }-40.0 \% \text { Bilirubin } \\
-42.1 \%\end{array}$ & NR \\
\hline $\begin{array}{l}\text { Herbinger (2016) Germany } \mathrm{N}= \\
51 \text {; All ages }\end{array}$ & $\begin{array}{l}\mathrm{AST}-64.7 \% \mathrm{ALT}-76.5 \% \mathrm{GGT} \\
-70.6 \%\end{array}$ & NR \\
\hline $\begin{array}{l}\text { Ishibashi (1987) Japan } N=9 \text {; } \\
\text { Adult }\end{array}$ & Transaminases - $100 \%$ & NR \\
\hline $\begin{array}{l}\text { Massei (2001) Italy } \mathrm{N}=54 \text {; All } \\
\text { ages }\end{array}$ & $\mathrm{ALT}-48.1 \% \mathrm{GGT}-20.4 \%$ & 12 weeks \\
\hline $\begin{array}{l}\text { Mazur (2019) Poland N = 181; } \\
\text { Paediatric }\end{array}$ & $\begin{array}{l}\mathrm{AST}-48.1 \% \mathrm{ALT}-49.2 \% \mathrm{GGT} \\
-26.5 \%\end{array}$ & NR \\
\hline $\begin{array}{l}\text { Monteiro (2020) Brazil N = 251; } \\
\text { All ages }\end{array}$ & $\begin{array}{l}\text { AST }-11.8 \% \text { ALT }-15.8 \% \text { GGT } \\
-25.0 \%\end{array}$ & NR \\
\hline $\begin{array}{l}\text { Mygind (1976) Denmark } \mathrm{N}=36 \text {; } \\
\text { Ages not specified }\end{array}$ & $\mathrm{AST}-69.4 \%$ & 10 weeks \\
\hline $\begin{array}{l}\text { Rotenburg (1991) Israel } N=82 \\
\text { Ages not specified }\end{array}$ & $\mathrm{AST}-69.5 \% \mathrm{ALT}-89.0 \%$ & NR \\
\hline $\begin{array}{l}\text { Sohn (2017) Korea N = 149; } \\
\text { Paediatric }\end{array}$ & $\mathrm{ALT}-71.1 \%$ & NR \\
\hline $\begin{array}{l}\text { Son (2011) Korea } \mathrm{N}=81 \text {; } \\
\text { Paediatric }\end{array}$ & $\mathrm{ALT}+/-\mathrm{AST}-51.9 \%$ & NR \\
\hline
\end{tabular}




\begin{tabular}{|c|c|c|}
\hline Study & Proportion of raised LFTs & $\begin{array}{l}\text { Maximum time to resolution of } \\
\text { LFTs }\end{array}$ \\
\hline $\begin{array}{l}\text { Sridhar (2018) Hong Kong } \mathrm{N}= \\
\text { 25; Adult }\end{array}$ & $\begin{array}{l}\text { AST - 100.0\% ALT - 96.0\% GGT } \\
-91.7 \% \text { ALP }-56.0 \% \text { Bilirubin - } \\
0 \%\end{array}$ & NR \\
\hline $\begin{array}{l}\text { Vanderhorst (1991) USA } \mathrm{N}= \\
\text { 120; Ages not specified }\end{array}$ & $\mathrm{AST}-43.1 \%$ ALT $-40.5 \%$ & NR \\
\hline $\begin{array}{l}\text { Zhang (2017) China } N=95 \text {; Ages } \\
\text { not specified }\end{array}$ & $\begin{array}{l}\text { No numerical values but 'ALT, } \\
\text { AST and GGT levels are } \\
\text { significantly increased in IM } \\
\text { patients compared to controls'; } \\
\text { 'bilirubin is lower compared to } \\
\text { controls' }\end{array}$ & NR \\
\hline $\begin{array}{l}\text { Gadeberg (1984) Denmark } N= \\
\text { 10; All ages }\end{array}$ & ALT $-88.9 \%$ & $>6$ weeks \\
\hline $\begin{array}{l}\text { Dommerby (1986) Denmark } \mathrm{N}= \\
\text { 29; All ages }\end{array}$ & $\begin{array}{l}\text { AST }-65.6 \% \text { ALP }-31.0 \% \\
\text { Bilirubin }-0.0 \%\end{array}$ & 17 weeks \\
\hline $\begin{array}{l}\text { Baehner (1967) USA N = 105; } \\
\text { Paediatrics }\end{array}$ & $\begin{array}{l}\text { AST }-24.4 \% \text { ALT }-35.6 \% \\
\text { Bilirubin }-15.6 \%\end{array}$ & NR \\
\hline $\begin{array}{l}\text { Kanegane (1997) Japan N = 54; } \\
\text { Paediatrics }\end{array}$ & $\begin{array}{l}\text { No numerical values but 'mean } \\
\text { AST and ALT values for all study } \\
\text { patients were abnormal' }\end{array}$ & NR \\
\hline $\begin{array}{l}\text { Henke (1973) USA N }=776 \text {; All } \\
\text { ages }\end{array}$ & Liver function $-53.8 \%$ & NR \\
\hline Rosalki (1960) UK N = 23; Adult & $\begin{array}{l}\text { AST }-78.3 \% \text { ALT }-82.6 \% \text { ALP - } \\
39.1 \% \text { Bilirubin }-13.0 \%\end{array}$ & 12 weeks \\
\hline $\begin{array}{l}\text { Shuster (1967) USA N = 46; Ages } \\
\text { not specified }\end{array}$ & $\begin{array}{l}\text { AST }-83.7 \% \text { ALP }-82.6 \% \\
\text { Bilirubin }-17.8 \%\end{array}$ & NR \\
\hline $\begin{array}{l}\text { Kilpatrick (1966) Germany } N= \\
\text { 20; Adult }\end{array}$ & $\begin{array}{l}\text { ALT }-65.0 \% \text { ALP }-38.9 \% \\
\text { Bilirubin }-6.7 \%\end{array}$ & NR \\
\hline $\begin{array}{l}\text { Grotto (2003) Israel } N=114 ; \\
\text { Adult }\end{array}$ & $\begin{array}{l}\text { AST }-34.7 \% \text { ALT }-53.2 \% \\
\text { Bilirubin }-14.9 \%\end{array}$ & NR \\
\hline $\begin{array}{l}\text { Gao (2011) China } N=418 \\
\text { Paediatric }\end{array}$ & $\mathrm{AST}+\mathrm{ALT}-48.6 \%$ & NR \\
\hline $\begin{array}{l}\text { Rea (2001) USA N = 140; All } \\
\text { ages }\end{array}$ & $\begin{array}{l}\text { AST }-31.4 \% \text { ALT }-61.4 \% \\
\text { Bilirubin }-5.7 \%\end{array}$ & $>6$ months \\
\hline $\begin{array}{l}\text { Ginsburg (1977) USA N = 30; } \\
\text { Paediatric }\end{array}$ & AST $-36.7 \%$ Bilirubin $-10.0 \%$ & NR \\
\hline Gelb (1962) USA N = 69; All ages & $\begin{array}{l}\text { AST }-83.0 \% \text { ALT }-84.1 \% \text { ALP }- \\
81.4 \% \text { Bilirubin }-42.9 \%\end{array}$ & 6 weeks \\
\hline $\begin{array}{l}\text { Finkel (1964) USA N = 235; Ages } \\
\text { not specified }\end{array}$ & $\begin{array}{l}\text { AST }-78.0 \% \text { ALT }-78.6 \% \text { ALP }- \\
76.3 \% \text { Bilirubin }-21.1 \%\end{array}$ & NR \\
\hline $\begin{array}{l}\text { Wang (2013) China } \mathrm{N}=287 \text {; All } \\
\text { ages }\end{array}$ & $\begin{array}{l}\text { AST }-74.1 \% \text { ALT }-74.7 \% \text { GGT } \\
-52.8 \% \text { Bilirubin }-12.6 \%\end{array}$ & $>12$ days \\
\hline $\begin{array}{l}\text { Topp (2015) Denmark N = 95; } \\
\text { Paediatric }\end{array}$ & ALT $-53.7 \%$ Bilirubin $-9.3 \%$ & NR \\
\hline $\begin{array}{l}\text { Baron (1965) UK N = 80; Ages } \\
\text { not specified }\end{array}$ & $\begin{array}{l}\text { AST }-72.5 \% \text { ALP }-55.2 \% \\
\text { Bilirubin }-37.7 \%\end{array}$ & 6 weeks \\
\hline $\begin{array}{l}\text { Evans (1948) USA N = 19; Ages } \\
\text { not specified }\end{array}$ & ALP $-42.9 \%$ Bilirubin $-36.8 \%$ & $>6$ weeks \\
\hline
\end{tabular}


Maximum time to resolution of

Study

Proportion of raised LFTs

LFTs

NR - Not reported

NR - Not reported

NR - Not reported

Table 3 Proportion of raised LFTs and maximum time to resolution of LFTs of individual studies

\section{Hosted file}

Figure 1 prisma selection diagram.docx available at https://authorea.com/users/376334/ articles/555645-the-utility-of-liver-function-tests-and-abdominal-ultrasound-ininfectious-mononucleosis-a-systematic-review

\section{Hosted file}

Table 1.docx available at https://authorea.com/users/376334/articles/555645-the-utility-ofliver-function-tests-and-abdominal-ultrasound-in-infectious-mononucleosis-a-systematicreview

\section{Hosted file}

Table 2.docx available at https://authorea.com/users/376334/articles/555645-the-utility-ofliver-function-tests-and-abdominal-ultrasound-in-infectious-mononucleosis-a-systematicreview

\section{Hosted file}

Table 3.docx available at https://authorea.com/users/376334/articles/555645-the-utility-ofliver-function-tests-and-abdominal-ultrasound-in-infectious-mononucleosis-a-systematicreview 